\title{
ВПЛИВ СПАДКОВОСТІ ГОЛШТИНСЬКОЇ ПОРОДИ НА РОЗВИТОК ЛІНІЙНИХ ОЗНАК КОРІВ-ПЕРВІСТОК УКРАЇНСЬКОї ЧОРНО-РЯБОЇ МОЛОЧНОї ПОРОДИ
}

\author{
Хмельничий Сергій Леонтійович \\ кандидат сільськогосподарських наук, ст. викладач \\ Сумський національний аграрний університет \\ ORCID:0000-0003-2352-3317 \\ E-mail: serhiokh@ukr.net \\ Повод Микола Григорович \\ доктор сільськогосподарських наук, профессор \\ Сумський національний аграрний університет \\ ORCID: 0000-0001-9272-9672 \\ E-mail: nic.pov@ukr.net \\ Самохіна Євгенія Анатоліївна \\ кандидат сільськогосподарських наук, доцент \\ Сумський національний аграрний університет \\ ORCID: 0000-0002-0983-3047 \\ E-mail: evgeniya_samokhina@ukr.net
}

Дослідження проведені задля вивчення мінливості з розвитку лінійних ознак екстер'єрного типу корів-первісток української чорно-рябої молочної породи залежно від впливу умовної кровності голштинської породи. Експериментальною базою служила селекційна інформація з лінійної класифікації корів племінного заводу ПП "Буринське” Підліснівського відділення Сумського району. Оцінка корів за типом проведена у межах трьох груп помісних тварин із умовною кровністю голштинської породи: I - 62,5-74,9; II - 75,0-87,4 ma 87,5 \% і вище.

Встановлено достовірний вплив умовної частки крові за поліпшуючою породою на екстер'єрний тип тварин. 13 нарощуванням спадковості голштинської породи у помісних корів збільшувалася оцінка за лінійні ознаки типу. Тварини III-ї групи були кращими за ровесниць l-ї та II-ї груп відповідно за груповими ознаками молочного типу на 2,9 та 0,8 балу, тулуба - на 2,9 та 1,3 балу, кінцівок - на 0,6 та 0,5 балу та вимені - на 2,8 та 0,6 балу. Фінальна оцінка зросла від 81,3 балу (корови першої групи із спадковістю голштина 62,5-74,9 \%) до 83,9 балу (корови III групи із спадковістю голштина 87,5 \% івище).

Перевищення висококровних помісей III-ї групи у порівнянні з I-ю та II-ю за описовими ознаками екстер'єру виявлено за глибиною тулуба, кутастістю, шириною заду, прикріпленням передніх та задніх часток вимені, центральною зв'язкою, глибиною вимені та довжиною дійок.

Результати досліджень дозволяють стверджувати, що нарощування спадковості голштинської породи істотно поліпшує екстер'єрний тип корів української чорно-рябої молочної породи, що варто враховувати у селекційному процесі удосконалення тварин цієї породи за екстер'єрним типом.

Ключові слова: українська чорно-ряба молочна порода, корови-первістки, лінійна очінка типу, голштинська порода, умовна кровність.

DOI: https://doi.org/10.32845/bsnau.lvst.2020.3.11

Досить важливим моментом селекційного процесу в аспекті генетичного поліпшення української чорно-рябої молочної породи $є$ визначення рівня впливу умовної частки кровності за поліпшувальною голштинською породою на розвиток лінійних ознак екстер'єру у помісних тварин. Хоча у процесі виведення новостворених українських порід і типів молочної худоби та на сучасному етапі їхнього удосконалення у напрямку консолідації пріоритети при доборі тварин надавалися й надаються не частці умовної кровності за будь-якою із вихідних порід, а вираженості у них бажаного молочного типу, притаманним цим породам $[1,4]$. Не менш важливим питанням в процесі консолідації породи залишається добір та підбір корів за бажаним екстер'єрним типом $[8,10,11,13]$.

Проте питання щодо оцінки ступеня впливу спадковості поліпшуючої породи на розвиток провідних господарськи корисних ознак корів молочних порід виключати не слід, оскільки до цього спонукає система селекційно-племінної роботи, яка вимагає достовірного, об'єктивного та системного аналізу селекційної ситуації у часі, в тому числі, виявлення характерних закономірностей щодо прояву генотипу в конкретних умовах племінного господарства, врахування яких дозволяє адекватно вживати дієвих заходів для ії поліпшення $[2,3,7,9]$. Тому для вивчення залежності розвитку лінійних ознак екстер'єру від спадковості поліпшувальної голштинської породи стало метою цих досліджень.

Матеріали та методи досліджень. Матеріалами експериментальних досліджень були селекційні дані з лінійної оцінки корів-первісток племінного заводу компанії "Укрлендфрармінг" ПП "Буринське" Підліснівського відділення Сумського району. Лінійна класифікація проведена у межах трьох груп помісних тварин із умовною кровністю за голштинською породою: I - 62,5-74,9; || - 75,0-87,4 та 87,5 \% і вище. Оцінка екстер'єрного типу корів-первісток проводилася за методикою лінійної класифрікації [12] згідно рекомендацій ICAR [5, 14] у віці 2-4 місяців після отелення за двома системами: 9-бальною, з лінійним описом 18 статей екстер'єру і 100-бальною 3 урахуванням чотирьох комплексів селекційних ознак, які характеризують: вираженість молочного типу, розвиток тулуба, 
стан кінцівок і морфологічні якості вимені. При цьому кожен із екстер'єрних комплексів оцінювався незалежно з певним ваговим коефіцієнтом у фінальній оцінці (ФО) тварини: молочний тип (МТ) - $15 \%$, тулуб (Т) - $20 \%$; кінцівки (К) - $25 \%$ та вим'я (В) $-40 \%$.

Фінальну оцінку типу визначали за формулою: $\Phi \mathrm{O}=(\mathrm{MT} \times 0,15)+(\mathrm{T} \times 0,20)+(\mathrm{K} \times 0,25)+(\mathrm{B} \times 0,40)$ Дані експериментальних досліджень опрацьовували біометричними методами на ПК у середовищі Microsoft Office Excel за використання програмного забезпечення за формулами, наведеними Е.К. Меркурьевой [6].

Результати досліджень. Наведені у таблиці результати лінійної оцінки корів-первісток різних генотипів свідчать про існування впливу умовної частки крові за поліпшуючою породою на екстер'єрний тип тварин.

При порівнянні трьох різних за генотипом груп корівпервісток племінного заводу ПП “Буринське”, оцінених за 100бальною системою лінійної класифікації, встановлено, що у помісних тварин із зростанням умовної кровності за голштинською породою суттєво покращується будова тіла та якість вимені. Так, за групою корів-первісток з умовною часткою крові 75,0-87,4\% за поліпшуючою породою спостерігається перевага над ровесницями у яких ця частка менша (62,5$74,9 \%$ ). Вона склала за комплексом ознак молочного типу 2,1 балу, тулуба - 1,6, вимені - 2,1 та за загальною оцінкою - 2,1 балу з високою достовірністю в усіх випадках порівнянь при $\mathrm{P}<0,001$ ( $\mathrm{td}=8,25-11,35)$, за виключенням кінцівок, де різниця становила - 0,9 балу при достовірності $\mathrm{P}<0,01$ ( $\mathrm{td}=3,18)$.

Аналогічно наступна група, з умовною кровністю голштина 87,5\% і вище, з достовірною різницею на 0,8 балу $(\mathrm{P}<0,001 ; \mathrm{td}=3,89)$ краща за попередню $(75,0-87,4 \%)$ за ознаками молочного типу, на 1,3 балу - за розвитком тулуба $(\mathrm{P}<0,001 ; \mathrm{td}=5,39)$, на 0,6 балу - за ознаками вимені $(\mathrm{P}<0,01$; $t d=2,58)$ та на 0,5 балу за загальною оцінкою типу $(P<0,01$; $\mathrm{td}=2,93)$. За ознаками, що характеризують стан кінцівок, висококровні помісні генотипи (87,5\% і >) поступалися групі корів 3 кровністю $75,0-87,4 \%$ на 0,3 балу за недостовірної різниці $(\mathrm{td}=1,14)$.

Що стосується описових лінійних ознак, то рівень оцінки за 9-ти бальною шкалою свідчить про кращий їхній розвиток у тварин з вищою умовною кровністю за голштинською породою $(87,5 \%$ і >). У порівнянні з двома помісними групами 3 нижчою умовною кровністю голштина - 62,5-74,9 та 75,0$87,4 \%$, корови-первістки висококровного генотипу істотно перевищували їх за оцінкою висоти, відповідно - на 0,8 і 0,3 балу, за достовірної різниці $(P<0,001)$ лише з першою групою $(62,5-74,9 \%)$.

Характеристика корів-первісток ПП “Буринське”з різною часткою умовної кровності голштинської породи за ознаками лінійної оцінки екстер'єрного типу, балів

\begin{tabular}{|c|c|c|c|c|}
\hline \multirow{3}{*}{\multicolumn{2}{|c|}{ Ознака екстер'єру }} & \multicolumn{3}{|c|}{ Умовна кровність голштинської породи, \% } \\
\hline & & І-ша гр. & ॥-га гр. & III-тя гр. \\
\hline & & $\begin{array}{c}62,5-74,9 \\
(n=72)\end{array}$ & $\begin{array}{c}75,0-87,4 \\
(n=108)\end{array}$ & $\begin{array}{l}87,5 i> \\
(n=144)\end{array}$ \\
\hline \multicolumn{2}{|c|}{$\begin{array}{l}\text { Комплекси ознак: } \\
\text { молочного типу }\end{array}$} & $81,1 \pm 0,18$ & $83,2 \pm 0,15$ & $84,0 \pm 0,14$ \\
\hline \multicolumn{2}{|c|}{ тулуба } & $82,5 \pm 0,19$ & $84,1 \pm 0,18$ & $85,4 \pm 0,16$ \\
\hline \multicolumn{2}{|l|}{ кінцівок } & $82,6 \pm 0,21$ & $83,2 \pm 0,19$ & $83,7 \pm 0,18$ \\
\hline \multicolumn{2}{|l|}{ вимені } & $81,1 \pm 0,18$ & $83,2 \pm 0,14$ & $83,8 \pm 0,15$ \\
\hline \multicolumn{2}{|c|}{ Фінальна оцінка } & $81,3 \pm 0,11$ & $83,4 \pm 0,11$ & $83,9 \pm 0,13$ \\
\hline \multicolumn{2}{|c|}{ Описові ознаки: висота } & $5,6 \pm 0,15$ & $6,1 \pm 0,12$ & $6,4 \pm 0,19$ \\
\hline \multicolumn{2}{|c|}{ ширина грудей } & $6,8 \pm 0,22$ & $6,1 \pm 0,21$ & $5,8 \pm 0,16$ \\
\hline \multicolumn{2}{|l|}{ глибина тулуба } & $6,1 \pm 0,21$ & $7,2 \pm 0,15$ & $7,7 \pm 0,17$ \\
\hline \multicolumn{2}{|l|}{ кутастість } & $5,2 \pm 0,18$ & $7,0 \pm 0,12$ & $7,5 \pm 0,14$ \\
\hline \multicolumn{2}{|l|}{ нахил заду } & $5,5 \pm 0,19$ & $5,1 \pm 0,13$ & $4,9 \pm 0,15$ \\
\hline \multicolumn{2}{|l|}{ ширина заду } & $5,3 \pm 0,18$ & $6,2 \pm 0,12$ & $6,8 \pm 0,16$ \\
\hline \multicolumn{2}{|c|}{ кут тазових кінцівок } & $5,9 \pm 0,21$ & $5,2 \pm 0,14$ & $4,8 \pm 0,19$ \\
\hline \multicolumn{2}{|c|}{ постава тазових кінцівок } & $6,9 \pm 0,18$ & $6,7 \pm 0,15$ & $6,5 \pm 0,18$ \\
\hline \multicolumn{2}{|l|}{ кут ратиць } & $5,9 \pm 0,15$ & $5,5 \pm 0,13$ & $5,1 \pm 0,17$ \\
\hline \multirow{2}{*}{$\begin{array}{l}\text { прикріплення } \\
\text { часток вимені: }\end{array}$} & передніх & $6,2 \pm 0,11$ & $6,8 \pm 0,14$ & $7,1 \pm 0,14$ \\
\hline & задніх & $5,9 \pm 0,13$ & $6,2 \pm 0,16$ & $6,8 \pm 0,14$ \\
\hline \multicolumn{2}{|c|}{ центральна зв'язка } & $5,4 \pm 0,23$ & $6,3 \pm 0,17$ & $6,7 \pm 0,15$ \\
\hline \multicolumn{2}{|c|}{ глибина вимені } & $5,2 \pm 0,25$ & $6,1 \pm 0,16$ & $6,4 \pm 0,13$ \\
\hline \multirow{2}{*}{$\begin{array}{l}\text { розташування } \\
\text { дійок: }\end{array}$} & передніх & $5,3 \pm 0,15$ & $4,8 \pm 0,14$ & $4,2 \pm 0,14$ \\
\hline & задніх & $5,5 \pm 0,14$ & $5,6 \pm 0,14$ & $5,4 \pm 0,14$ \\
\hline \multicolumn{2}{|l|}{ довжина дійок } & $6,1 \pm 0,19$ & $5,5 \pm 0,12$ & $5,2 \pm 0,09$ \\
\hline \multicolumn{2}{|c|}{ переміщення (хода) } & $6,8 \pm 0,20$ & $6,6 \pm 0,16$ & $6,2 \pm 0,20$ \\
\hline \multicolumn{2}{|c|}{ вгодованість } & $6,9 \pm 0,22$ & $5,8 \pm 0,18$ & $5,2 \pm 0,19$ \\
\hline
\end{tabular}

Перевищення висококровних помісей за описовими ознаками екстер'єру виявлено також за оцінкою глибини тулуба - відповідно на 1,6 ( $\mathrm{P}<0,001)$ і 0,5 $(\mathrm{P}<0,05)$ балу, кутастості - на 2,3 ( $\mathrm{P}<0,001)$ і 0,5 ( $\mathrm{P}<0,01)$, ширини заду - на 1,5 $(P<0,001)$ і $0,6(P<0,01)$, прикріплення передніх - на 0,9 $(P<0,001)$ і 0,3 (н/дост.) та задніх часток вимені - на 0,9 $(P<0,001)$ і 0,6 ( $P<0,01)$, центральної зв'язки - на 1,3 ( $P<0,001)$ і 0,4 (н/дост.), глибини вимені - на 1,2 (P<0,001) і 0,3 (н/дост.) та довжини дійок - на 0,9 $(P<0,001)$ і 0,3 $(P<0,05)$ балу.

Згідно з даними оцінки у висококровних за голштином корів-первісток III-ї групи істотно зменшилась ширина грудей, у порівнянні з першими двома групами, відповідно - на 1,0 $(P<0,001)$ та 0,3 балу (н/дост.). Якщо серед корів І-ї групи ча- 
стіше зустрічалися тварини із шаблистістю (5,9 балу), то серед корів III-ї зросла частка тварин зі слоновістю у скакальному суглобі (4,8 балу). Погіршився у них також стан кута ратиць - на 0,8 балу $(P<0,001)$ у порівнянні з помісями І-ї групи та на 0,4 балу - у порівнянні з II-ю групою $(P<0,05)$. Поступалися корови-первістки III-ї групи за оцінкою вгодованості з різницею на користь І-ї групи - на 1,7 балу $(\mathrm{P}<0,001)$ та II-ї - на
1,1 балу $(P<0,001)$.

Висновки. Результати досліджень дозволяють стверджувати, що нарощування спадковості голштинської породи істотно поліпшує екстер'єрний тип корів української чорно-рябої молочної породи.

\section{Список використаної літератури:}

1. Адміна Н. Г. Оцінка бугаїв за екстер'єрними особливостями дочок. Розведення і генетика тварин. 2010. Вип. 44. С. 28-29.

2. Зубець М. В., Буркат В. П., Єфіменко М. Я. [та ін.] Генетико-селекційний моніторинг у молочному скотарстві: за ред. В. П. Бурката. К. : Аграрна наука, 1999. 88 с.

3. Клопенко Н. І., Ставецька Р. В. Генетична детермінація господарського використання корів молочного напряму продуктивності за вбирного схрещування. Технологія виробництва і переробки продукції тваринництва : зб. наук. праць Білоцерківського НАУ. 2015. Вип. 1. С. 23-28.

4. Клопенко Н. І. Морфологічні особливості вим'я української чорно- рябої молочної худоби за використання голштинської худоби. Сучасні проблеми селекції, розведення та гігієни тварин : зб. наук. праць Вінницького НАУ. Вінниця, 2012. Вип. 3(61). C 83-88.

5. Ладика В. І., Хмельничий Л. М., Буркат В. П., Рубан С. Ю. Реєстрація ICAR. Довідник. Суми: Сумський національний аграрний університет, 2010. 457 c.

6. Меркурьева Е. К. Генетические основы селекции в скотоводстве. М. : Колос, 1977. 240 с.

7. Пелехатий М. С., Кочук-Ященко О. А. Вплив генотипу корів-первісток української чорно-рябої молочної породи на їх екстер'єрний тип, молочну продуктивність і відтворну здатність. Наук. вісник ЛНУВМ ім. С. 3. Гжицького. Львів, 2014. Т.16, № 3, ч. 3. С. $143-158$.

8. Пелехатий М. С., Піддубна Л. М. Концепція бажаного типу та ї̈ використання при створенні високопродуктивного заводського стада молочної худоби. Вісник Житомирського НАЕУ. 2012. Т.1, № 1. С. 238-247.

9. Полупан Ю. П. Онтогенетичні та селекційні закономірності формування господарськи корисних ознак молочної худоби : дис. ... доктора с.-г. наук : 06.02.01; Ін-т розведення і генетики тварин НААН. с. Чубинське Київської обл., 2013.694 с. C. $261-269$

10. Хмельничий Л. М. Бажаний екстер'єрний тип корів молочної породи. Розведення і генетика тварин. 2007. Вип. 41.

11. Хмельничий Л. М. Бажаний тип як критерій добору корів молочної худоби за екстер'єром. Вісник Сумського НАУ. Серія: “Тваринництво”. 2010. Вип. 10(18). С. 137-149.

12. Хмельничий Л. М., Ладика В. І., Полупан Ю. П., Братушка Р. В., Прийма С. В., Вечорка В. В. Лінійна класифікація корів молочних і молочно-м'ясних порід за типом. (Методичні вказівки) - 2-е вид., перероб. і доп. Суми : Сумський національний аграрний університет, 2016. 27 с.

13. Хмельничий Л. М. Оцінка екстер'єру тварин в системі селекції молочної худоби : монографрія / Л. М. Хмельничий. Суми : Мрія, 2007. 260 с.

14. ICAR Guidelines for Conformation Recording of Dairy Cattle, Beef Cattle and Dairy Goats, 1/76. Section - 5, Conformation Recording, version June, 2018. [Електронний ресурc]. - Режим доступу: https://www.icar.org/Guidelines/05-ConformationRecording.pdf

\section{References:}

1. Admina, N. H., 2010. Otsinka buhaiv za eksteriernymy osoblyvostiamy dochok [Estimation of bulls by conformation features of daughters]. Rozvedennia i henetyka tvaryn, issue 44, pp. 28-29.

2. Zubets', M. V., Burkat, V. P., Yefimenko, M. Ya. [et. al]. 1999. Burkat, V. P., ed. Henetyko-selektsiynyy monitorynh u molochnomu skotarstvi [Genetics and breeding monitoring in Dairy cattle]. K.: Ahrarna nauka, 88.

3. Klopenko, N. I. and Stavets'ka, R. V., 2015 Henetychna determinatsiia hospodarskoho vykorystannia koriv molochnoho napriamu produktyvnosti za vbyrnoho skhreshchuvannia. [Genetic determination of cow's economic use dairy direction of productivity by absorbing crossing]. Tekhnolohiia vyrobnytstva i pererobky produktsii tvarynnytstva: Zb. nauk. prats Bilotserk. nats. ahrar. un-ta. Bila Tserkva, issue 1, pp. 23-28.

4. Klopenko, N. I., 2012. Morfolohichni osoblyvosti vymia ukrainskoi chorno- riaboi molochnoi khudoby za vykorystannia holshtynskoi khudoby [Morphological features of udder Ukrainian Black-and-White dairy cattle using of Holstein cattle]. Suchasni problemy selektsii, rozvedennia ta hihiieny tvaryn : zb. nauk. prats Vinnytskoho NAU. Vinnytsia, issue 3(61), pp 83-88.

5. Ladyka, V. I., Khmel'nychyi, L. M., Burkat, V. P. and Ruban, S. Yu. 2010. Reyestratsiya ICAR. Dovidnyk [ICAR Registration: Reference book]. Sumy: Sumy National Agrarian University. Kolos, 240.

6. Merkur'eva, E. K., 1977. Geneticheskie osnovy selektsii v skotovodstve [Genetic bases of selection in livestock]. Moskva:

7. Pelekhatyy, M. S. and Kochuk-Yashchenko, O. A., 2014. Vplyv henotypu koriv-pervistok ukrainskoi chorno-riaboi molochnoi porody na yikh eksteriernyi typ, molochnu produktyvnist i vidtvornu zdatnist [Genotype influence of cows first-calf Ukrainian Black-andWhite dairy breed on their conformation type, milk productivity and reproductive ability]. Nauk. visnyk LNUVMB im. S. Z. Hzhytskoho. 
Lviv, no. (3), pp. 143-158.

8. Pelekhatyy, M. S. and Piddubna, L. M., 2012. Kontseptsiia bazhanoho typu ta yii vykorystannia pry stvorenni vysokoproduktyvnoho zavodskoho stada molochnoi khudoby [Concept of the desired type and its use in creating a highly productive stud herd of dairy cattle]. Visnyk Zhytomyrskoho NAEU. Zhytomyr, no. (1), pp. 238-247.

9. Polupan, Yu. P., 2000. Povtoryaemost' i vzaimosvyaz' instrumental'noy i glazomernoy otsenki ekster'era krupnogo rogatogo skota [Repeatability and interrelation of instrumental and visual assessment of the cattle conformation]. Sel'skokhozyaystvennaya biologiya, no. 2, pp. 108-114.

10. Khmelnychyi, L.M., 2007. Bazhanyi eksteriernyi typ koriv molochnoi khudoby [Desired exterior type of dairy cattle]. Rozvedennia i henetyka tvaryn, issue 41, pp. 261-269.

11. Khmelnychyi, L. M., 2010. Bazhanyi typ yak kryterii doboru koriv molochnoi khudoby za eksterierom [Desired type as a criterion for selecting dairy cattle by conformation]. Visnyk Sumskoho NAU, issue 10(18), pp. 137-149.

12. Khmelnychyi, L. M., Ladyka, V. I., Polupan, Yu. P., Bratushka, R. V., Pryima, S. V. and Vechorka, V. V., 2016. Liniina klasyfikatsiia koriv molochnykh i molochno-miasnykh porid za typom [Linear classification of dairy and dairy-meat cows by type]. (Metodychni vkazivky) 2-e vyd., pererob. i dop. Sumy : Sumskyi Natsionalnyi Ahrarnyi Universytet, 27.

13. Khmelnychyi, L. M., 2007. Otsinka eksterieru tvaryn v systemi selektsii molochnoi khudoby: monohrafiia [Estimation of animal conformation in the breeding system of dairy cattle: monograph]. Sumy: "Mriya-1", 260.

14. ICAR Guidelines for conformation recording of dairy cattle, beef cattle and dairy goats, $1 / 76$. Section 5 , Conformation gecording, version june, 2018. [Elektronniy resurs]. Rezhim dostupu: https://www.icar.org/Guidelines/05-Conformation-Recording.pdf

Khmelnychyi Serhii Leontievych, Ph.D. of Agricultural Sciences, Art. teacher

Povod Mykola Grigorovich, Doctor of Agricultural Sciences, Professor

Samokhina Evgeniya Anatoliyivna, Ph.D. of Agricultural Sciences, Associate Professor

Sumy National Agrarian University (Sumy, Ukraine)

The influence of Holstein breed inheritance on the development of linear traits cows firstborn of Ukrainian black-andwhite dairy cattle

The research was conducted to study the variability in the development of linear traits of the conformation type of firstborn cows of Ukrainian Black-and-White dairy breed depending on the influence of the conditional blood of Holstein breed. The experimental basis was the selection information on the linear classification of cows of the breeding farm PE "Buryn'ske" Pidlisnivsky branch of Sumy region. Assessment of cows by type was carried out within three groups of crossbred animals with conditional blood of Holstein breed: I - 62.5-74.9; II - 75.0-87.4 and 87.5\% and above.

A significant effect of the conditional proportion of blood by the improving breed on the conformation type of animals had been established. With increase in the inheritance of Holstein breed in crossbred cows, the score for linear traits of the type increased. Animals of the III group were better than their peers from I and II groups, respectively, by group traits of dairy type by 2.9 and 0.8 score, body - by 2.9 and 1.3 score, limbs - by 0,6 and 0.5 score and udder - by 2.8 and 0.6 score. The final grade increased from 81.3 score (cows of the first group with Holstein inheritance 62.5-74.9\%) to 83.9 score (cows of group III with Holstein inheritance $87.5 \%$ and above).

Excess of high-blood hybrids in the III group compared with the I-st and II-nd by descriptive traits of conformation was revealed on body depth, angularity, rear width, front and rear udder parts attachment, central ligament, udder depth and teats length.

The research results suggested that increasing inheritance of Holstein breed significantly improved cow's conformation type of Ukrainian Black-and-White dairy breed, which should be taken into account in the selection process of improving animals of this breed by conformation type.

Key words: Ukrainian Black-and-White dairy breed, first born cows, linear type assessment, Holstein breed, conditional blood

Дата надходження до редакції: 21. 10.2020 р. 